Vasyl ZHELYKH ${ }^{1}$

Olena SAVCHENKO ${ }^{2}$

Vadym MATUSEVYCH

\title{
THE APPLICATION FEATURES GEOTHERMAL VENTILATION OF THE PASSIVE HOUSE IN THE COLD SEASON
}

\begin{abstract}
To maintain permissible parameters in a passive house must be installed mechanical ventilation system. To previous preheat outside air for ventilation system is advisable to use low potential energy of the Earth. Currently, the implementation using ground-air heat exchanger requires extensive parametric studies, development and implementation of engineering calculation methods, a comprehensive study of the possibilities of effective exploitation. Technical prerequisites of use ground-air heat exchanger of geothermal ventilation and the results of analytical studies determining the temperature of the soil at different depths during the year are shown in the article. The graphical dependences of soil temperature during cold season for different values of depths of the heat exchanger laying are obtained. According to the research the recommended depth of laying of ground-air heat exchangers for Lviv was determined.
\end{abstract}

Keywords: passive house, ground-air heat exchanger, depth of laying, soil temperature, cold season

\section{Introduction}

The concept of passive building emerged based on numerous scientific and technical research concerning energy-saving technologies and modern level requirements for the use of energy resources. Passive house is a building standard. It is example energy saving in building industry.

${ }^{1}$ Author for correspondence: Vasyl Zhelykh, National University "Lviv Polytechnic", Institute of Building and Environmental Engineering, 79013, Lviv - 13, St. Bandery street, 12, +380322582705, v_zhelykh@msn.com

2 Olena Savchenko, Lviv Polytechnic National University, Institute of Building and Environmental Engineering, 79013, Lviv - 13, St. Bandery street, 12, +380508681814, o.savchenko@i.ua

3 Vadym Matusevych, REHAU LLC, 79034, Lviv-34, Luhanska str., 18, +380504367825, vadymm2004@ukr.net 
The maintaining of permissible parameters of microclimate indoors using mechanical ventilation is one of the main requirements in the design of passive houses. Total primary energy consumption of passive house (primary energy for heating, ventilation, hot water and electricity) must not be more than $120 \mathrm{kWh} / \mathrm{m}^{2}$ per year. The building must be designed to have an annual heating demand as calculated with the condition of not more than $15 \mathrm{kWh} / \mathrm{m}^{2}$ per year in heating [2]. The fan which provides air movement in the ventilation system and air heater are consumers of energy in the ventilation system.

Air heaters are used to heat the outside air in the cold season before entering it into the rooms. As the heaters are used various types of heat exchangers, water, electrical, etc. They use thermal or electrical energy. For primary energy savings in the ventilation systems of passive houses is recommended to use recuperator. They allow heat supply air due to the heat extract air. Currently, there are ways to preheat outside air due to low potential energy of the soil.

\section{Purpose of work}

Defining preconditions and technical possibilities of using of low potential energy soil for the first heating outside air of ventilation system passive house in the cold season.

\section{Analysis of existing studies}

The soil surface layers of the Earth are a natural heat accumulator. The main source of heat that enters the soil is solar radiation. The soil temperature depends on seasonal changes of oscillation in ambient temperature too. The thermal conductivity that is caused by the difference of temperatures different soil layers, and heat capacity of the soil affect the heat transfer between the soil surface and it's deep layers. Thermal diffusivity of soil $a$ characterizes the rate of change of temperature due to absorption or return of heat. It depends on ratio solid, liquid and gaseous components, textural and structural characteristics ratio of soil and its moisture. Thermal diffusivity, $\mathrm{m}^{2} / \mathrm{s}$, determined by the formula:

$$
a=\frac{\lambda}{\rho \cdot C},
$$

where: $\lambda$ - coefficient of thermal conductivity of the soil, $\mathrm{W} /(\mathrm{m} \cdot \mathrm{K})$,

$$
\rho \text { - density of soil, } \mathrm{kg} / \mathrm{m}^{3} \text {, }
$$

$C$ - specific heat of the soil, $\mathrm{kJ} /(\mathrm{kg} \cdot \mathrm{K})$.

The value of thermal conductivity, density and specific heat of certain types of soils is given in Table $1[4,5]$. Daily temperature oscillations in the soil are distributed to a depth of to $1 \mathrm{~m}$, and seasonal variations $-10 \mathrm{~m}$. The soil at depths below $10 \mathrm{~m}$ is almost not exposed to seasonal temperature oscillations. Penetration of solar radiation to the deep layers of soil carried out with lateness. Thus, the daily extreme for each $10 \mathrm{~cm}$ depth is delayed by $2.5-3.5$ hours. 
The annual maximum and minimum are delaying 20 - 30 days for every $1 \mathrm{~m}$ depth [3]. Thus, at a depth of 4 meters from the surface layers the temperature potential of soil in the cold season is much higher than the outside air, and the warm season - much lower.

Table 1 . The thermal conductivity, density and specific heat of certain of soils

Tabela 1. Przewodność cieplna, gęstość i ciepło właściwe niektórych gruntów

\begin{tabular}{|l|c|c|c|}
\hline \multicolumn{1}{|c|}{ The types of soils } & $\rho,\left[\mathrm{kg} / \mathrm{m}^{3}\right]$ & $C,[\mathrm{~kJ} /(\mathrm{kg} \cdot \mathrm{K})]$ & $\lambda,[\mathrm{W} /(\mathrm{m} \cdot \mathrm{K})]$ \\
\hline Alumina & $2300-2400$ & 0.88 & 2.33 \\
\hline Limestone & 2650 & 0.92 & 1.70 \\
\hline Dry sand & 1500 & 0.80 & 0.33 \\
\hline Sand with humidity of $10 \%$ & 1500 & 0.80 & 0.97 \\
\hline Sand with humidity of $20 \%$ & 1500 & 0.80 & 1.33 \\
\hline Sandy ground & $1500-2000$ & $1.10-3.32$ & 1.16 \\
\hline Moist soil & $1900-2000$ & 2.0 & \\
\hline Soil dry & $1400-1600$ & 0.84 & 0.40 \\
\hline Soil compacted & $1600-2000$ & $1.0-3.0$ & 1.05 \\
\hline
\end{tabular}

This temperature potential of the soil surface layers currently used to produce thermal energy for heating and ventilation systems. The transmission of heat from the soil to the coolant carried in ground-air heat exchangers. The pipe of heat exchanger made of a material that has a high coefficient of thermal conductivity for ensure highly effective heat transmission from soil to coolant. The special coating is applied on the internal surface of the pipeline to eliminate the possibility of the formation of bacteria.

1 - air intake unit,

2 - horizontal ground-air

heat exchangers,

3 - recuperator,

4 - supply air,

5 - extract air,

6 - air air extract unit

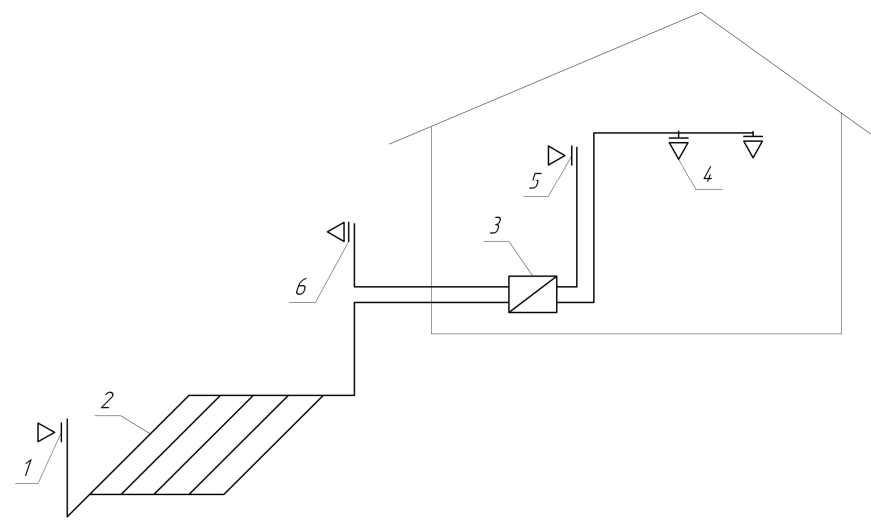

Fig. 1. Schematic diagram of the geothermal ventilation

Rys. 1. Schemat ideowy wentylacji geotermalnej

In ventilation systems low potential energy of soil is used for the first heating outside air in the cold season. Cold outside air is moved in soil heat exchangers and is heated through the wall of the heat exchanger whose temperature is equal 
to temperature of the soil. The second heating of outside air in ventilation systems in passive house occurs in heat recuperators. Therefore, the temperature at the exit of ground-air heat exchanger should be more than the freezing temperature of heat recuperator. For peak heating ventilation supply air should use of additional heating devices (heat pumps, electric heaters, etc.). Scheme of geothermal ventilation passive house is shown in Figure 1.

\section{Analytical studies}

Options for placement of ground-air heat exchangers, soil temperature and depth of the placement of heat exchangers are the main technical prerequisites for using ground heat exchangers in the ventilation systems of passive houses.

According to [2], currently there are two types of placement of ground-air heat exchangers (Figure 2): Domestic loop layout or Tichelmann pipe layout. [1] In the cold season due to low heat transfer soil to provide the desired temperature at the outlet of the heat exchanger should take into account important factors such as length, diameter and number of tubes of ground-air heat exchangers.

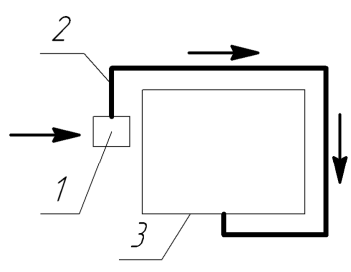

a

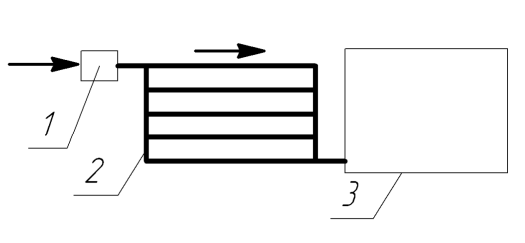

b
1 - air intake unit,

2 - ground-air heat exchanger,

3 - house.

Fig. 2. Options for placement of horizontal ground-air heat exchangers of geothermal ventilation. a) - Domestic loop layout, b) - Tichelmann pipe layout.

Rys. 2. Możliwości ustawienia poziomych wymienników ciepła ziemia-powietrze wentylacji geotermalnej. a) - gospodarczy układ pętli, b) - układ rury Tichelmann`a .

For buildings with little air exchange from 120 to $250 \mathrm{~m}^{3} / \mathrm{h}$ the Domestic loop layout of ground heat exchangers can maintain the desired temperature [1]. This primarily applies to buildings with volume up to $500 \mathrm{~m}^{3}$, since according to the passive house concept their multiplicity of air exchange is $0.51 / \mathrm{h}$. This statement is based on the famous calculation dependence of air exchange on the multiplicity:

$$
L=k \cdot V \text {, }
$$

where: $k$ - the multiplicity of air exchange, $1 / \mathrm{h}$, $V$ - volume of the room, $\mathrm{m}^{3}$.

If there is free plot of soil then should be used Tichelmann pipe layout. Such pipe layout is allowing to increase the temperature at the outlet of the heat 
exchanger and thus save primary energy for heating of supply air of ventilation system.

The soil temperature affects the thermal efficiency of soil heat exchanger. This is due to the process of heat exchange between soil and coolant. The temperature can be determined by the formula for the known characteristics of the soil and the depth of layout of ground-air heat exchanger [6]:

$$
T_{S}(h, t)=\overline{T_{S}}-A \cdot e^{-h \sqrt{\frac{\pi}{365 a}}} \cdot \cos \left(\frac{2 \pi}{365}\left[t-t_{o}-\frac{h}{2} \sqrt{\frac{365}{\pi \cdot a}}\right]\right),
$$

where: $\mathrm{x}$ - depth of soil, $\mathrm{m}$;

$\overline{T_{S}}$ - the annual average surface temperature of the soil taken equal an annual average outdoor air temperature for the selected region, ${ }^{\circ} \mathrm{C}$; $\mathrm{t}$ - day of the year;

A - annual amplitude fluctuation of the surface temperature of the soil, ${ }^{\circ} \mathrm{C}$, a - thermal diffusivity of the soil, $\mathrm{m}^{2} / \mathrm{s}$;

$t_{0}$ - time lag (in days) from a random initial date of the emergence of the minimum temperature in year.

Using formula (3) for Lviv the temperatures soil at a depth $1.5-5.0 \mathrm{~m}$ for the months of the cold season year were determined. Data of these calculations are shown in Figure 3.

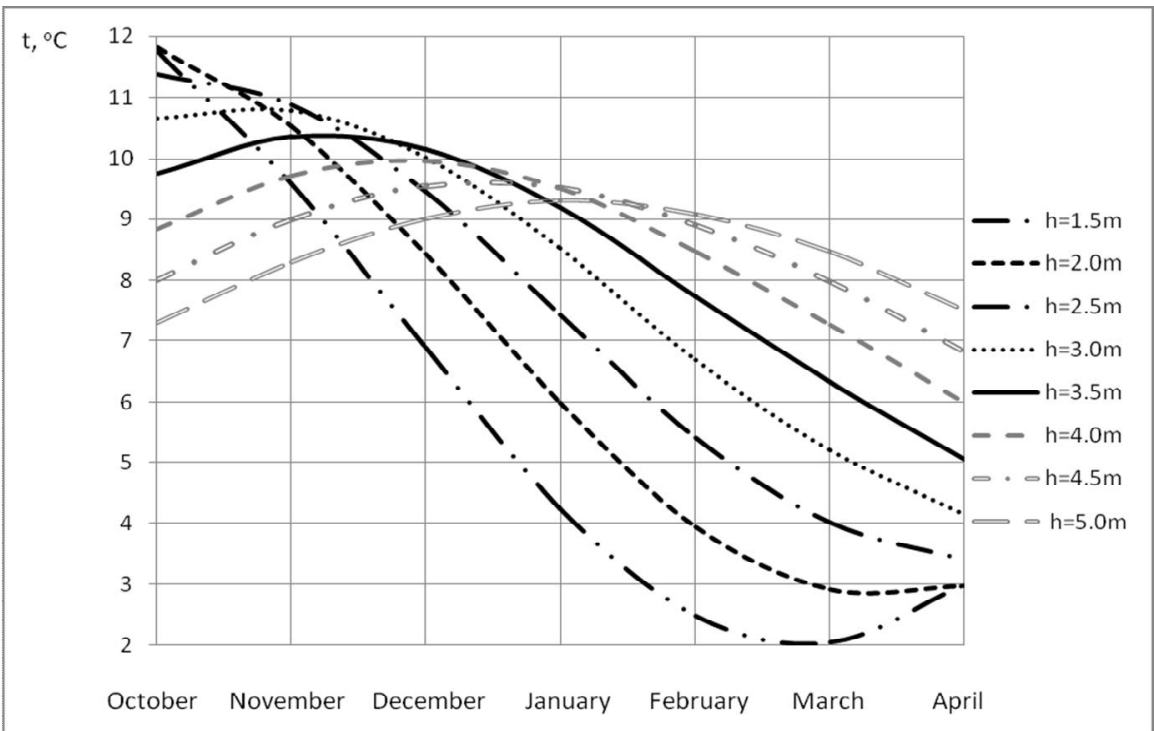

Fig. 3. Temperature variation with depth for cold season of the year for Lviv

Rys. 3. Zmiany temperatury na głębokości w sezonie zimowym roku dla Lwowa 
As shown in Figure 3, the maximum soil temperature observed at a depth of $2.0 \mathrm{~m}$ for the month of October, and the minimum - at a depth of $1.5 \mathrm{~m}$ in March. The biggest change of temperature from the soil depth is in February and is in the range of 2 to $9{ }^{\circ} \mathrm{C}$, and the lowest in November - from 8 to $11^{\circ} \mathrm{C}$. The amplitude of the temperature variations of soil with increasing depth varies from $10{ }^{\circ} \mathrm{C}$ at a depth of $1.5 \mathrm{~m}$ to $2.5^{\circ} \mathrm{C}$ at a depth of $5.0 \mathrm{~m}$. With further increase the depth of laying of the ground-air heat exchanger the soil temperature is not changes, and is $9-10{ }^{\circ} \mathrm{C}$. However, increasing the depth of laying the heat exchanger leads to increase the capital costs of the ventilation system. That is why, depth laying the ground-air heat exchanger is determined from the feasibility calculation of geothermal ventilation.

Thus, with increasing depth laying of heat exchanger the stability work of geothermal ventilation system is provided, because daily oscillations outside air is not influencing by it. This allows efficient use of the heat of the Earth for the first heating of supply air geothermal ventilation in the cold season.

\section{Conclusion}

The analysis of the data revealed that in January the maximum soil temperature at a depth of $4.5 \mathrm{~m}$, and in February and March - at a depth of $5.0 \mathrm{~m}$. The difference between the values of soil temperature at depths of $4.0-5.0 \mathrm{~m}$ in February and March is insignificant. Thus, the technical conditions for the use of ground-air heat exchanger for Lviv was reviewed. The recommended depth of their laying was determined, it is equal to $3.5 \mathrm{~m}$.

\section{Bibliography}

[1] AWADUKT thermo ground-air heat exchanger. Renewaible cooling solution for low energy buildings. London, REHAU Ltd, 2012.

[2] Passivhaus Vorprojktierung 2002. PHVP 2002. Energiebilanzverfahren furr die Vorentwurfsplanung von Passivhausern. - Darmstadt: Passiv Haus Institut, 2002. - $42 \mathrm{p}$

[3] http://geology.lnu.edu.ua/phis_geo/fourman/E-books-FVV/Interactive\%20books/ Meteorology/Meteo-climat/Meteo-termics.htm [access: 12 March $2013 \mathrm{r}$.]

[4] http://www.infrost.ru/tech_info/coefficient [access: 13 March 2013 r.]

[5] http://www.dpva.info/Guide/Guide Physics/GuidePhysicsHeatAndTemperature/ SpecificHeat/SpecificHeatTable/ [access: 13 March 2013 r.]

[6] http://www.intechopen.com/books/energy-conservation/earth-shelters-a-review-ofenergy-conservation-properties-in-earth-sheltered-housing [access: 31 October 2012]. 


\section{STOSOWANIE URZĄDZEŃ WENTYLACJI GEOTERMALNEJ DOMU PASYWNEGO W SEZONIE ZIMOWYM}

\section{Streszczenie}

Zachowanie wymaganych parametrów domu pasywnego jest możliwe jedynie przy zainstalowaniu mechanicznych systemów wentylacyjnych. Do wstępnego podgrzania zewnętrznego powietrza dla systemu wentylacyjnego, wskazane jest użycie niskiej energii potencjalnej Ziemi. Obecnie, stosowanie wymiennika ciepła ziemia-powietrze wymaga szeroko zakrojonych badań parametrycznych, rozwoju i wprowadzenie inżynierskich metod obliczeniowych, oraz wszechstronnych badań nad możliwościami skutecznego ich wykorzystywania. W artykule zostały przedstawione techniczne warunki wstępnego wykorzystania wymiennika ciepła geotermalnej wentylacji ziemia-powietrze i wyniki badań analitycznych określających temperaturę gleby w ciągu roku przy różnych głębokościach. Określono zależność temperatury gleby podczas sezon zimnego na poziom układania wymiennika ciepła. Na podstawie badań została określona zalecana głębokość układania wymienników ciepła ziemia - powietrze dla miasta Lwowa.

Słowa kluczowe: dom pasywny, wymiennik ciepła ziemia - powietrze, głębokość układania, temperatura gruntu, sezon zimowy

Przestano do redakcji:8.06.2015

Przyjęto do druku:1.12.2015

DOI: $10.7862 / \mathrm{rb} .2015 .172$ 